\title{
sciendo
}

\section{LUNAR PERIODICITY IN REPRODUCTION OF SENATORIAL SCALLOP (Chlamys senato- ria GMELIN, 1791) IN ASID GULF, MASBATE, PHILIPPINES}

\author{
Christian D. Cabiles
}

Agriculture Department, Catanduanes State University-Panganiban Campus, Panganiban, Catanduanes, 4806, Philippines

*Corresponding Author: christian.cabiles@bicol-u.edu.ph

\section{ARTICLE INFO}

Received: 2 March 2020

Accepted: 3 March 2021

\section{Keywords:}

Reproduction

Lunar periodicity

Exogenous factors

Scallop

\section{ABSTRACT}

In Masbate, senatorial scallop Chlamys senatoria is one of the five commercially important species of scallop present in Asid Gulf, but its basic biology is poorly understood in the Philippines. To provide biological information for future conservation and management, the reproductive rhythm of senatorial scallop in relation to lunar phase was investigated from October 2016 to March 2017. Scallops were collected daily from the fishers' catches and were measured, dissected, and processed for histological analysis; whereas, fecundity and size of eggs (diameter) were also determined. Ecological parameter such as bottom water temperature was monitored during the sampling period. Results showed that $C$. senatoria is a highly fecund species, which ranges from $8.3 \times 10^{5}$ to $2.1 \mathrm{X}$ $10^{6}$ oocytes per female and its sizes (oocytes) ranges from $53.8 \mu \mathrm{m}$ to 72.5 $\mu \mathrm{m}$ while Gonado-somatic index (GSI) ranges from 3.2 to 7.1. Fecundity, egg diameter, and the GSI decreased during new moon (NM) and full moon (FM). GSI indicates that the onset of spawning activity commences during NM and FM. Environmental parameters that were monitored showed significant variations in relation to lunar phase. Spawning of scallop C. senatoria follows a lunar reproductive pattern, which was initiated and influenced by the variations of different factors such as temperature, water amplitude, and light as the effect of lunar/tidal cycles. These findings indicate that reproduction and necessarily spawning in the scallop are related to factors associated with lunar phases. Strategies for managing the resource can be formulated using the temporal dimension of lunar phases.

Cabiles, C. D. (2021): Lunar periodicity in reproduction of senatorial scallop (Chlamys senatoria Gmelin, 1791) in Asid Gulf, Masbate, Philippines. Croatian Journal of Fisheries, 79, 137-146. DOI: 10.2478/cjf-2021-0015. 


\section{INTRODUCTION}

Scallops are of worldwide economic important invertebrates in aquatic ecosystem that support both commercial fisheries and commercial efforts (Shumway and Parsons, 2016). They are commercially exploited for human consumption, which is considered as luxury food in many countries (Wong, 2016) that are highly nutritious as they are rich in glycogen and protein (Minchin, 2003; Hardy, 2006). Having a wide geographical distribution from polar to tropical regions, the scallop $C$. senatoria belong to the family Pectinidae, which is a diversed group of bivalve molluscs with more than 30 genera and 400 species inhabiting from shallow intertidal waters up to a depth of 7,000 meters worldwide (Brand, 2006; Telahigue et.al., 2018). In the Philippines, scallops were reported to occur in Lingayen Gulf and Visayan Sea (Del Norte, 1991) particularly in Asid Gulf (Soliman and Dioneda, 2004) and Gigantes Island (Morillo-Manalo et al., 2016; Acabado et al., 2018). For instance, five commercially important scallop species including $C$. senatoria were reported inhabiting the Asid Gulf (Soliman and Dioneda, 2004 ) that supports the need of people in terms of food and livelihood (Cabiles et al., 2019). The gulf is part of the Visayan Sea, which is a large body of water reported to be the only remaining site in the Philippines to have a large volume of scallops thriving in their natural habitat where they are fished commercially (Bobiles and Soliman, 2018). Scallops reproductive biology have been extensively conducted worldwide (Cabiles and Soliman, 2019); whereas, several methods were reported as means of assessing its gametogenesis and reproduction. These include microscopic (histological) (Dukeman et al., 2005; Sarkis et al., 2006; Morillo-Manalo et al., 2016), macroscopic (visual) gonadal staging (Naidu, 1970; Lefort and Clavier, 1993), and gonado-somatic index (GSI) (Sarkis et al., 2006; Morillo-Manalo et al., 2016; Sienes et al., 2018). The combination of GSI and histological analysis were the most common methods used to assess the reproductive pattern of scallops; wherein, the combination of these methods gives reliable information for reproductive development (Cabiles and Soliman, 2019). According to Sastry (1970 and 1979), scallops, like other marine bivalves, have reproductive cycles that are genetically-controlled response to the environment. They spawn throughout the year (Dukeman et al., 2005; Morillo-Manalo et al., 2016) and that all gonad stages are present each month (Morillo-Manalo et al., 2016). The continuous spawning and the occurrence of these stages throughout a month may suggest lunar rhythm (Sienes et al., 2018). Reproductive synchrony with lunar cycles may have evolved because the cycles of the moon offer reliable time cues to which reproductive behavior can be synchronized (Skov et al., 2005). However, the influence of lunar cycle on the reproductive biology remains a gap for most of the tropical bivalve species like scallops (Tran et al., 2011; Hamli et al., 2015).
Therefore, the general aim of this study is to determine the reproductive rhythm of $C$. senatoria relative to lunar cycle in Asid Gulf, Philippines. Specifically, the study focuses on the determination of the changes in fecundity, egg diameter, and GSI, in relation to environmental parameters such as bottom water temperature, tidal cycle, and moon illumination, which were affected by lunar/tidal cycle. Knowledge on this aspect is important as baseline data on its reproductive biology and for understanding and predicting recruitment events. The information that were generated may serve as reference to Local Government Unit (LGU), to the Fisheries managers and to the Bureau of Fisheries and Aquatic Resources (BFAR) in formulating certain management scheme to conserve the natural stocks. People, whose livelihood are intensely dependent on these species, are the direct beneficiaries of this study as the results will likewise help them to have a sustainable resource in the future.

\section{Study site}

Asid Gulf (Fig. 1) is one of the commercially major fishing grounds found at the Visayan Sea $\left(12^{\circ} 10^{\prime} 46^{\prime \prime} \mathrm{N}\right.$; $123^{\circ} 29^{\prime} 57^{\prime \prime} \mathrm{E}$ ), which is reported to be the only remaining site in the Philippines to have a large volume of scallops thriving in their natural habitat where they are fished commercially (Bobiles and Soliman, 2018; Buban et al., 2020). It is bordered by five coastal towns from Jintotolo Island of Balud (in the southwest) through Milagros, Cawayan, Placer, and Esperanza (in the southeast). The scallop production that beds in the Gulf are within the Recodo Marine Fishery Reserve (RMFR) and portion of the beds is in the adjacent coastal towns (Mendoza and Soliman, 2017), which include Pananawan, Malbug, Pina Island, Naro Island, Guinlubngan, and Namatyan.

\section{Monitoring of environmental parameters}

To have a reliable data on daily changes of bottom water temperature, a data logger was deployed on the bottom $(20 \mathrm{~m})$ where the scallops inhabit. The data logger was checked monthly to keep it clean from algae and to check if it is well-functioning. After three months, the first data logger was retrieved, and another data logger was deployed on the same site. On the other hand, tide table of Cebu was used to monitor daily changes in water amplitude on the study sites. While data on light intensity (moon illumination) was taken from "vercalendario. info", which give details on daily moon information in the Philippines such as moon illumination, distance, and the likes.

\section{Collection of samples}

Ten live female scallops $C$. senatoria were collected daily from the catches of hired divers throughout the six months study period. Collection of samples covers the minor and major spawning event of the species under study

\section{MATERIAL AND METHODS}




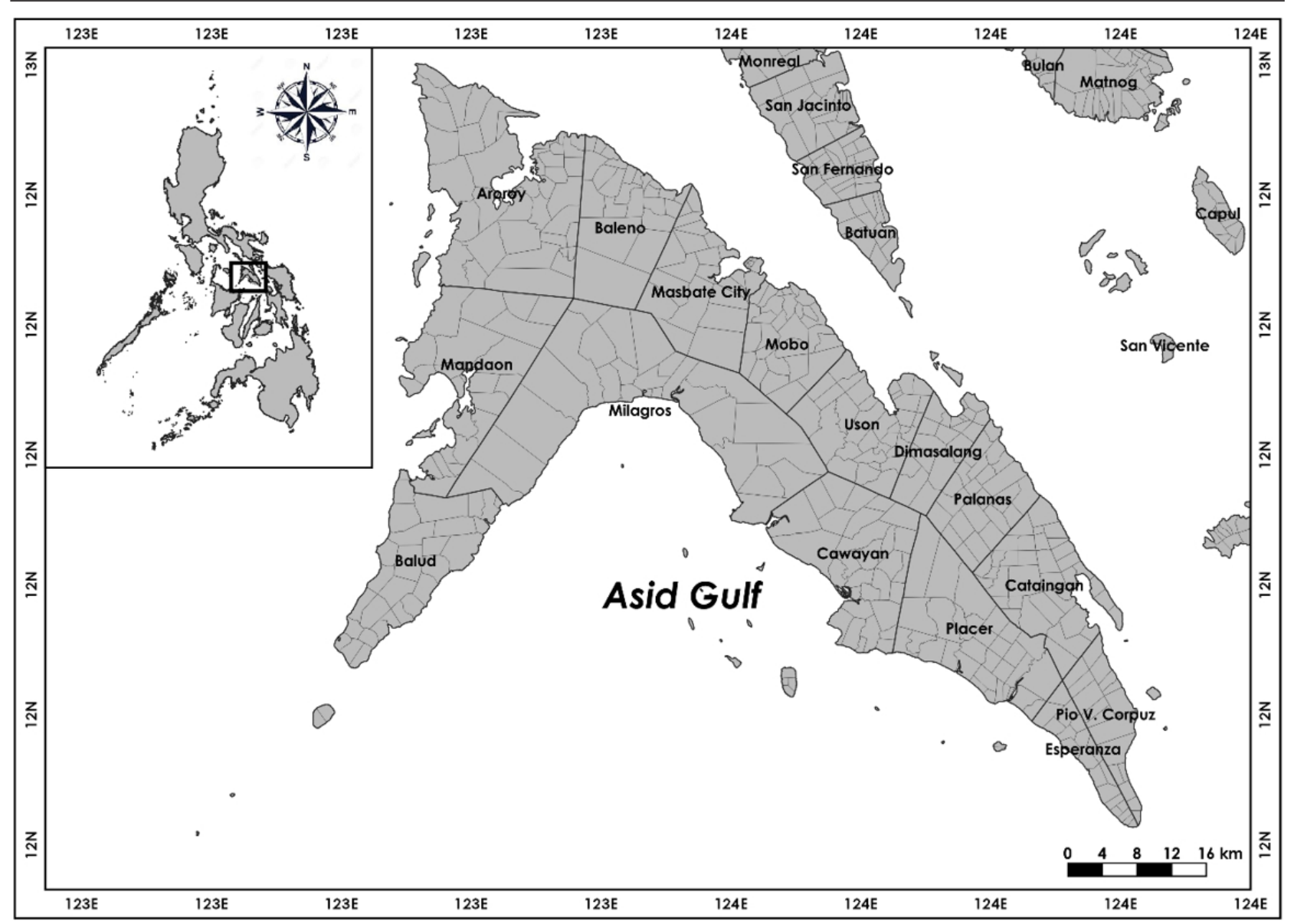

Fig 1. Map of the study site

(Morillo-Manalo et al., 2016). Weather conditions were also considered in the collection of samples; whereas, collection only commenced during weather conditions that are favorable for scallop diving.

\section{Preserving of samples}

Before transporting them to the laboratory, the 10 female C. senatoria were then preserved in a $10 \%$ formalin solution to avoid deterioration of their internal parts, particularly the gonads. The $10 \%$ formalin is a $1: 10$ dilution of $100 \%$ formalin in distilled water (1 part formaldehyde diluted in 9 parts water). Since 100\% formalin contains a $37 \%$ formaldehyde, a $1: 10$ dilution contained $3.7 \%$ formaldehyde.

\section{Weighing of samples}

The total weight of the individually preserved sample was determined using analytical balance to the nearest 0.01 g. Dissection of samples commenced after the process to separate the gonad from the other parts. Each gonad was weighed using the analytical balance; and were again preserved in a $10 \%$ formalin solution for histological analysis.

\section{Determination of Gonado-somatic index}

Gonado-somatic index (GSI) was calculated daily; a relationship was considered between the total weight and gonad weight of the individual sample. Dissection of the individual sample was done and the determination of gonadal weight using analytical balance commenced after the process. GSI of $C$. nobilis was computed using the formula:

$$
\mathrm{GSI}=[(\text { Gonad weight }(\mathrm{g})) /(\text { Total weight }(\mathrm{g}))] \cdot 100
$$

\section{Estimation of fecundity}

Estimation of fecundity (number of eggs) was done using gravimetric method, wherein a $0.1 \mathrm{~g}$ sub-sample from each gonad was used. The samples were placed in a petri dish and teased manually to separate the follicles. Separated follicles were put in the beaker to which a 100 $\mathrm{ml}$ tap water was added. Three replicate sub-sample of $1 \mathrm{ml}$ each were obtained, and oocytes were counted using a compound microscope. Fecundity (F) was estimated as:

$F=\frac{\text { Mean no. of oocytes } \cdot \text { Volume of samples }}{\text { Volume of subsample }} \cdot \frac{\text { Weight of samples }}{\text { Weight of subsample }}$ 


\section{Gonadal staging}

To properly determine the changes in gonadal development of female $C$. senatoria, two random samples were taken daily from the month of October and March, which represent the cold and warm months covered by the study. Randomly-selected individual samples were submitted for histological analysis at the Hi-Precision Laboratory, wherein the slides preparation was likewise conducted. Interpretation of the histological results, such as the gonadal staging and egg measurement, was done in Bicol University.

\section{Measurement of egg diameter}

Daily samples that undergo histological analysis were used for the egg measurement. Because the scallop eggs are irregular in shape, the longest dimension was recorded as the diameter (Fuerte and Baez, 1993). Measurement was done using Applied Vision 4 software, wherein 20 randomly-selected oocytes per sample were measured.

\section{Data Analysis}

This study applied quantitative research design; collected data sets were subjected to descriptive statistics such as mean and standard deviation. Regression analysis was established to test the relationship among the parameters collected such as dependent variables namely fecundity, egg diameter, and GSI to independent variables namely water amplitude, water temperature, and moon illumination. One-way analysis of variance was used to identify the possible differences between the test variables (dependent and independent) in relation to lunar phase. After finding out if the ANOVA was significant, a Tukeys test was conducted to identify which among the variables were significantly different in relation to lunar phase. Multiple regression analysis was used to determine which among the independent variables greatly affect the variations of dependent variables, specially in spawning of $C$. senatoria.

\section{RESULTS}

Fecundity in scallop C. senatoria of $57-86 \mathrm{~mm}$ shell height, corresponding to $19.6-84 \mathrm{~g}$ ranged from $8.3 \times 10^{5}$ to 2.1 $X 10^{6}$ oocytes per female. The mean fecundity for the six months study period was $1.4 \times 10^{6}\left( \pm 3.9 \times 10^{5}\right)$ eggs, and it varies in relation to lunar cycle. Individual samples with higher fecundity were observed during First Quarter (FQ) and Last Quarter (LQ) lunar phase with $1.8 \times 10^{6}( \pm 2.1 \times$ $\left.10^{5}\right)$ and $1.6 \times 10^{6}\left( \pm 2.9 \times 10^{5}\right)$ eggs respectively. However, decrease in fecundity was observed in the individuals collected during New Moon (NM) and Full Moon (FM) with $1.0 \times 10^{6}\left( \pm 1.6 \times 10^{5}\right)$ and $1.3 \times 10^{6}\left( \pm 11.6 \times 10^{5}\right)$ eggs. Throughout the six months study period, decrease in fecundity was consistently observed during NM and FM; whereas, increase in fecundity was consistently observed during FQ and LQ lunar phase.
Fecundity of $C$. senatoria varies in relation to exogenous factors such as water amplitude, water temperature, and moon illumination. Decrease in fecundity was observed during $\mathrm{NM}$ and $\mathrm{FM}$ in association with the increase in water amplitude (Fig. 2), decrease (FM) and increase (NM) in water temperature (Fig. 3), and when the highest (FM) and lowest (NM) light intensity were recorded (Fig. 4). Decrease in fecundity could possibly be attributed by the spawning event of the individual during NM and FM lunar phase.

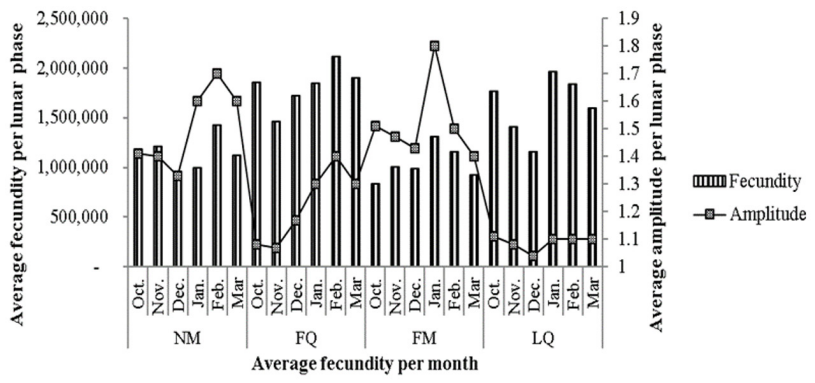

Fig 2. Fecundity of $C$. senatoria in relation to water amplitude (NM - New moon; FQ - First quarter; FM - Full moon; LQ - Last quarter)

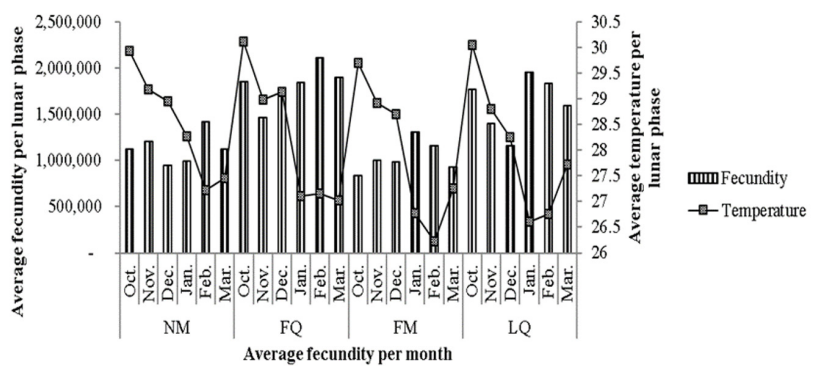

Fig 3. Fecundity of $C$. senatoria in relation to bottom water temperature (NM - New moon; FQ - First quarter; FM Full moon; LQ - Last quarter)

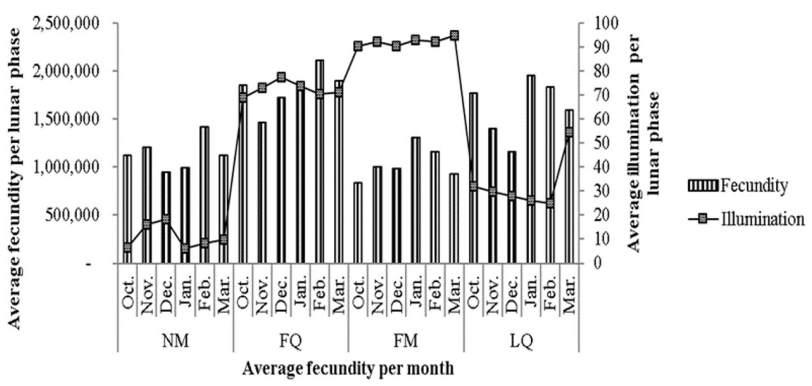

Fig 4. Fecundity of $C$. senatoria in relation to moon illumination (NM - New moon; FQ - First quarter; FM Full moon; LQ - Last quarter)

Egg sizes (diameter) of $C$. senatoria ranged from $53.8 \mu \mathrm{m}$ to $72.5 \mu \mathrm{m}$. The mean oocyte diameter was $61.5 \mu \mathrm{m}( \pm 6.7)$ and sizes varied in relation to lunar cycles. Larger size of eggs were both observed from the individuals collected during FQ $(70.5 \mu \mathrm{m} \pm 2.9)$ and LQ $(63.2 \mu \mathrm{m} \pm 2.3)$ lunar 
phase; whereas, smaller sizes of eggs were observed in the individuals collected during NM $(54.0 \mu \mathrm{m} \pm 0.3)$ and FM $(58.6 \mu \mathrm{m} \pm 1.6)$. Analysis of variance test (Two-way factor) revealed that the sizes of eggs in relation to lunar phases were significantly different $(P<0.05)$.

Variations on the egg sizes of $C$. senatoria were noticeable in relation to exogenous factors namely water amplitude, water temperature, and moon illumination. Smaller sizes of eggs were dominantly observed during NM and FM when there was an increase in water amplitude (Fig. 5), decrease (FM) and increase (NM) in water temperature (Fig. 6), and when the highest and lowest light intensity was recorded (Fig. 7). In contrast, larger sizes of eggs were observed when water amplitude was decreasing, and when the bottom water temperature and moon illumination were on its average variation.

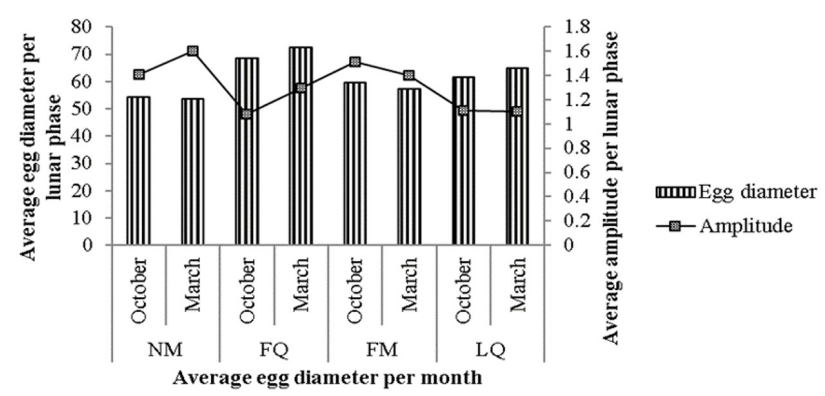

Fig 5. Egg diameter of $C$. senatoria in relation to water amplitude (NM - New moon; FQ - First quarter; FM - Full moon; LQ - Last quarter)

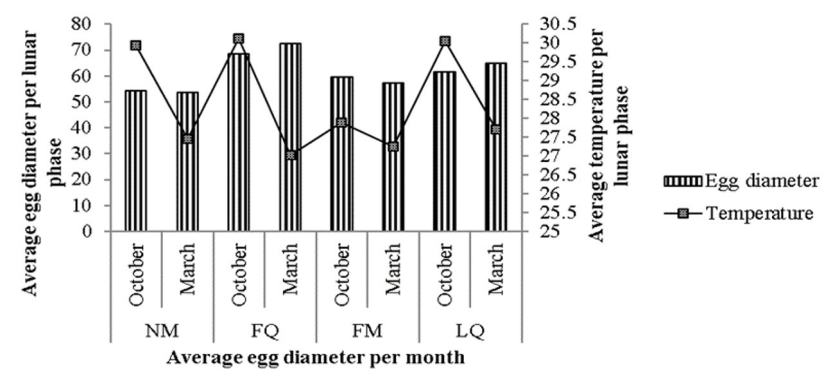

Fig 6. Egg diameter of $C$. senatoria in relation to bottom water temperature (NM - New moon; FQ - First quarter; FM - Full moon; LQ - Last quarter)

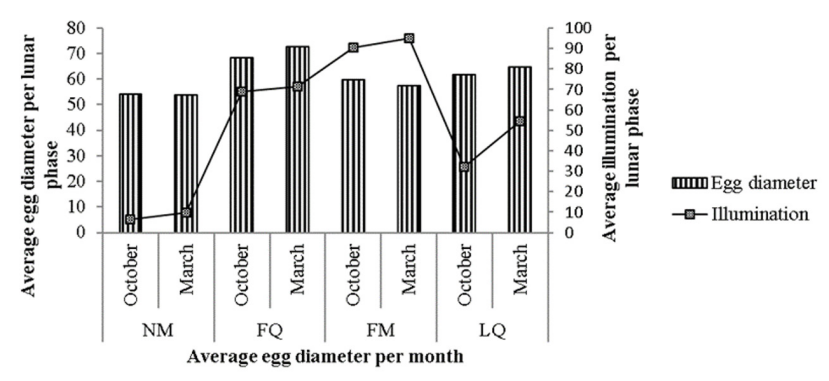

Fig 7. Egg diameter of $C$. senatoria in relation to moon illumination (NM - New moon; FQ - First quarter; FM Full moon; LQ - Last quarter)
GSI of scallop $C$. senatoria ranged from a minimum of 3.2, which was observed during NM to a maximum of 7.1 during FQ. The mean GSI was $4.9 \pm 1.1$. Variation on GSI followed a lunar periodicity, wherein, values decreased during NM (4.3 \pm 0.8$)$ and FM $(4.0 \pm 0.5)$ however, it increased during FQ $(5.8 \pm 0.9)$ and LQ $(5.4 \pm 1.1)$ lunar phase.

Variation on GSI of C. senatoria showed functional relationship with the variations of environmental parameters such as water amplitude, water temperature, and moon illumination. Decrease in GSI, which indicates spawning activity, occurred during NM and FM in association with the increase in water amplitude (Fig. 8), when the highest and lowest average temperature occurred (Fig. 9), and during the absence and highest light intensity (moon illumination) recorded (Fig. 10). However, increase in GSI was observed during FQ and LQ lunar phase when water amplitude decreases, and when the bottom water temperature and moon illumination were on its average variation.

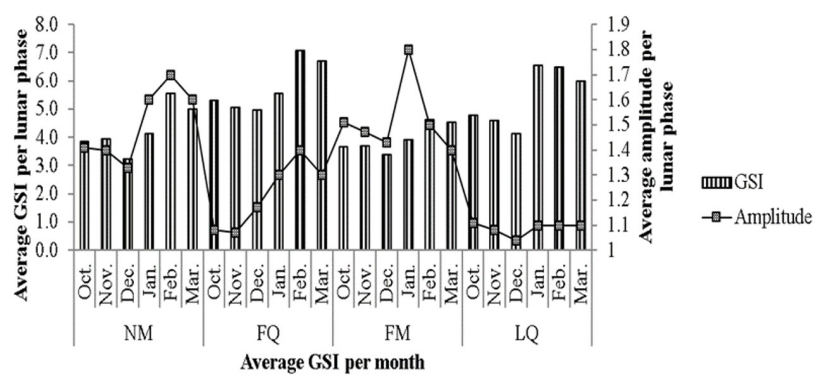

Fig 8. Gonado-somatic index of $C$. senatoria in relation to water amplitude (NM - New moon; FQ - First quarter; FM - Full moon; LQ - Last quarter)

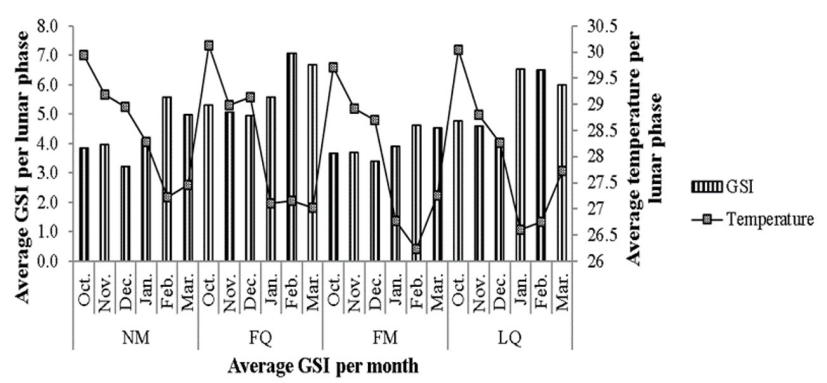

Fig 9. Gonado-somatic index of $C$. senatoria in relation to bottom water temperature (NM - New moon; FQ - First quarter; FM - Full moon; LQ - Last quarter)

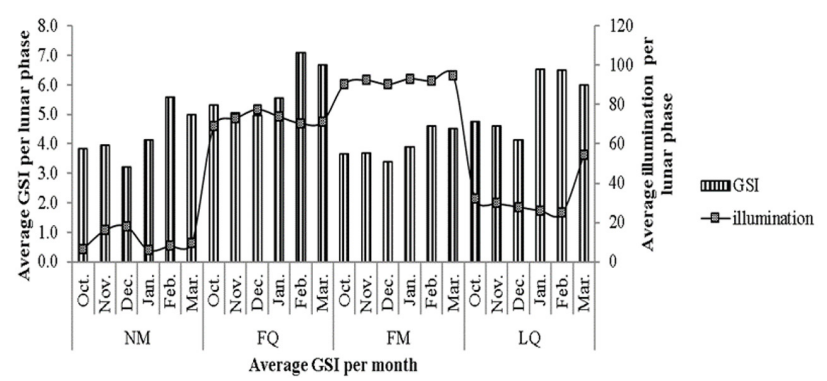

Fig 10. Gonado-somatic index of $C$. senatoria in relation to moon illumination (NM - New moon; FQ - First quarter; FM - Full moon; LQ - Last quarter) 
Results of histological analysis of gonad showed five distinct stages of maturity for female scallop $C$. senatoria: developing, matured, partially-spawned, spent, and redeveloping. Gonadal stages vary in relation to lunar phase. $\mathrm{NM}$ and FM were mostly dominated by partially spawned individuals, whereas, matured oocytes were dominated during FQ and LQ lunar phase. Fig. 11 shows the relative frequency of gonad stages for female scallop $C$. senatoria.

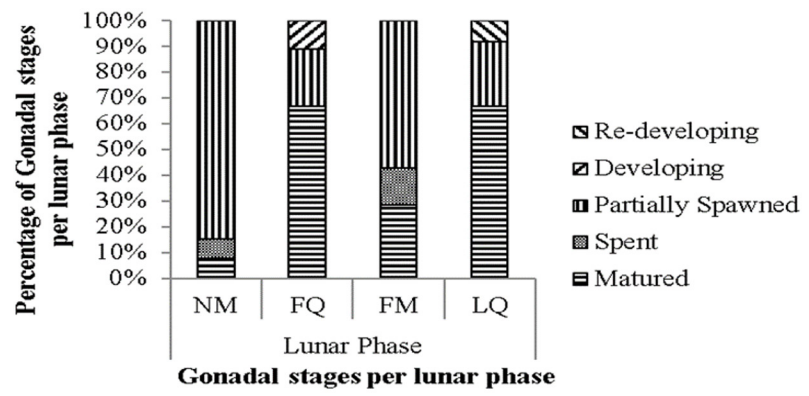

Fig 11. Relative percentage of the five distinct gonadal stages for female $C$. senatoria (NM - New moon; FQ - First quarter; FM - Full moon; LQ - Last quarter)

\section{DISCUSSION}

The fluctuations of different environmental parameters both in intertidaland sub-tidal areas in aquatic environment are primarily driven by the complex association of the sun-earth-moon orbit. Changes in these environmental parameters can be perceived by the marine animals and can affect its life histories such as behavioral, physiological, as well as reproduction to assure an optimum synchrony with the environment (Yamahira, 2004; Tran et al., 2011). In the present study, environmental parameters that were monitored showed variability in relation to lunar cycle. Such changes act as an important spawning cue for the species to synchronize reproduction. The most favorable combination of heavy spawning of the species was increase water amplitude during spring tides, lowest and highest bottom water temperature, and extreme light intensity (lowest and highest), which were observed during NM and FM. Coupling reproduction within these two lunar phases serve many advantages both for the spawners and to the newly hatch larvae. For instance, water amplitude shows significant variation in relation to lunar cycle and the species time its spawning during spring tides. Same findings were observed in the scallop Placopecten magellanicus Gmelin, 1791, Pecten maximus Linnaeus, 1758 and Chlamys opercularis Linnaeus, 1758 wherein spawning of these species were tidally related (Amirthalingam, 1928; Stevenson, 1936; Tang, 1941; Dickie, 1953; Mason, 1958). The correspondence of spawning event during spring tide (NM and FM) suggests that water amplitude together with other local environmental conditions such as pressure or currents, biological form of food availability, and chemical factors such as the pheromones, which are correlated with tidal cycle, act as important environmental spawning cue. Furthermore, spawning during NM and FM, where spring tide occurs, may facilitate the speedy offshore movement of larvae away from estuaries and coastal water, where predators and other environmental stresses are high (Johanes, 1978).

Water temperature is the environmental factor most often cited to influence bivalve reproduction, wherein either an increase or decrease in temparature is considered as the most important factor in the initiation of spawning (Naidu, 1970; Sastry, 1979; Cabiles and Soliman, 2019). In the present study, bottom water temperature varied in relation to lunar cycle. Variations could possibly the effect of tidal mixing and increase in water amplitude brought by the lunar-tidal cycle (Parsons et al., 1992). Spawning of C. senatoria both occured when water temperature was in its minimum and maximum average value during NM and FM. Some species of scallops where the spawning coincides with the decrease in water temperature includes Argopecten irradians concentricus Say 1822 (Sastry 1963, Barber and Blake 1983), Argopecten irradians irradians Lamarck 1819 (Tettelbach et al., 1999), and Argopecten gibbus Linnaeus 1758 (Miller et.al., 1981); whereas, spawning associated with an increase in temperature includes Chlamys opercularis Linnaeus 1758 (Ursin, 1956), Chlamys islandica Muller 1776 (Thorarinsdottir 1993), Amusium balloti Bernardi 1861 (Heald and Caputi, 1981), and Patinopecten yessoensis Jay 1857 (Kawamata, 1983). Moon illumination is one of the exogenous factors that act as a cue in the initiation of spawning (Barber and Blake, 1991) on the Pectinids due to their great number of eyes; thus, highly sensitive to light impressions (Korringa, 1947). In the present study, spawning of $C$. senatoria was significantly related to moon illumination. Spawning occurred during the lowest and highest average light intensity (moon illumination) recorded (NM and FM). Findings of this study concured with the findings of Amirthalingam 1928 that reproductive activity (spawning) of the Pecten opercularis Linnaeus 1758 occurred during full moon similarly in Pecten maximus Linnaeus, 1758 (Tang, 1941), Littorina saxatilis Olivi, 1792 (Berry and Smith, 1987), and Siphonoria denticulata Quoy \& Gaimard 1833 (Creese, 1980). Synchronous spawning in the absence and presence of moonlight has different advantages. Birth during nights without moonlight, especially during new moon, could reduce predation by visual hunters (Johannes, 1978) while spawning during full moon might facilitate migration to spawning sites (Colin et al., 1978). Thus, synchronized spawning may increase fertilization success (Olive et al., 2000).

The combination of exogenous factors namely bottom water temperature, water amplitude, and moon illumination have a different role and effect in the initiation of gametogenesis, likewise in the synchronization of spawning event (Gosling, 2003). This is evident in Pectinid species where reproduction is genetically-controlled 
response to the environment (Sastry, 1970). In the present study, $C$. senatoria showed bi-modal spawning event and tended to follow a lunar pattern in reproduction, wherein the direction of spawning occurred during NM and FM. Changes in fecundity, size of eggs, and GSI as dependent variables showed a similar trend in relation to lunar cycles. Decreasing values of these variables were observed consistent during NM and FM; whereas, increasing values were both observed during $F Q$ and LQ lunar phase. Decreasing number of eggs (fecundity) and its size (diameter) together with the lower recorded GSI are results of spawning activity of the organism (Barber and Blake, 1991). According to McDowall (1970), species in diverse phyla like Mollusca, mostly exhibit lunar rhythm in reproduction, wherein spawning and growth are influenced by the lunar periodicity (Lucas and Southgate, 2012). Lunar periodicity in reproduction also observed in Ostrea edulis Linnaeus, 1758 (Orton, 1926), Tridacna squamosa Lamarck, 1819 (Tan and Yasin, 2001), Littorina saxatilis (Berry and Smith, 1987), Siphonoria denticulata (Creese, 1980), Chlamys opercularis (Wilson, 1951), Pecten maximus (Mason, 1958), Meretrix meretrix Linnaeus, 1758 and Katelysia hiantina Lamarck, 1818 (Sienes et al., 2018). Coupling reproduction with lunar cycles may have evolve because the cycles of the moon offer reliable time cues to which reproductive behavior can be synchronized (Skov et al., 2006). Furthermore, the lunar-related spawning of the species under study could possibly be the effect of species' adaptation in the so called "bet-hedging" strategy, which retard reproductive activity when environmental parameters are not suitable for the spawning to occur (Parsons et al., 1992). On the other hand, if the environmental parameters were favorable for reproduction, synchronous spawning takes place. This strategy adopted by scallops ensures the favorable environmental conditions for the survival of larvae (Langton et al., 1987). These findings indicate that reproduction and necessarily spawning in the scallop are related to factors associated with lunar phases. Therefore, strategies for managing the resource can be formulated using the temporal dimension of lunar phases.

\section{CONCLUSIONS}

Chlamys senatoria is a highly fecund species. Variation of fecundity, egg diameter, and GSI were primarily attributed by the spawning activity. The species showed bi-modal and consistent pattern of reproduction in relation to lunar phase, which occurs during new moon and full moon. Retard spawning of the species during FQ and LQ promotes gonadal maturity during the times when environmental parameters were not favorable for reproduction to occur, whereby individuals with matured oocytes dominate within these lunar phases. In contrast, favorable environmental spawning cue during NM and FM initiates spawning, whereby partially-spawned individuals dominate within these two lunar phases.
The most favorable combinations for heavy spawning of the species were (a) increase water amplitude during spring tides, (b) lowest and highest bottom water temperature, and (c) extreme light intensity (lowest and highest). On the other hand, substantial (but not heaviest) spawning occured during neap tide under FQ and LQ lunar phase.

In general, gametogenic activity particularly spawning of C. senatoria are genetically-controlled response to the environment with the proper stimulus provided by the variations of bottom water temperature, water amplitude, and moon illumination.

Based from the results of the study, major spawning of $C$. senatoria in Asid Gulf occured in the month of December, therefore, harvesting the species on the said month should be regulated specifically during NM and FM to ensure that the species could reproduce and contribute to the natural stock. Studies on other environmental factors (i.e., food availability) that may act as a cue for spawning should be done to completely explain the reproductive rhythm of the species in Asid Gulf. Development of IEC materials about the importance and reproduction of $C$. senatoria should be made to properly educate the authority and the Islanders on the present status of this peculiar resource in the gulf.

\section{ACKNOWLEDGMENT}

The author wishes to thank all the people who have been part for the accomplishment of this study. Special acknowledgment are given to Victor S. Soliman, Ronnel R. Dioneda Sr., Antonino B. Mendoza Jr., Plutomeo M. Nieves, Grace B. Brizuela, Renan U. Bobiles, Maria Luisa U. Tango, local officials and scallop divers of Naro Island, Cawayan, Masbate for the full support during the conduct of this study. Your efforts are highly appreciated and treasured.

\section{UTJECAJ MJESEČAVIH MIJENA NA REPRODUK- CIJU ŠKOLJKAŠA (Chlamys senatoria GMELIN, 1791) U ZALJEVU ASID, MASBATU, FILIPINI}

\section{SAŽETAK}

U Masbateu, jedan od pet komercijalno važnih vrsta prisutnih u zaljevu Asid je školjkaš Chlamys senatoria, međutim njegova osnovna biologija je slabo razumljiva na Filipinima. Kako bi se osigurale biološke informacije za buduće očuvanje i upravljanje, istražen je reproduktivni ritam Chlamys senatoria u odnosu na mjesečevu fazu od listopada 2016. do ožujka 2017. godine. Školjkaši su se svakodnevno sakupljali iz ulova ribara, mjerili, secirali i obrađivali za histološku analizu, a utvrđivala su se i plodnost i veličina jaja (promjer). Ekološki parametar, kao što je temperatura vode na dnu, praćen je tijekom razdoblja uzorkovanja. Naši rezultati su pokazali da je $C$. 
senatoria visoko plodna vrsta, s brojem oocita od $8,3 \mathrm{X}$ $10^{5}$ do $2,1 \times 10^{6}$ po ženki, a veličine (oocita) se kreću od $53,8 \mu \mathrm{m}$ do $72,5 \mu \mathrm{m}$, dok se gonado-somatski indeks (GSI) kreće od 3,2 do 7.1. Plodnost, promjer jaja i GSI smanjuju se za vrijeme mladog mjeseca (NM) i punog mjeseca (FM). GSI ukazuje da početak mrijesta počinje tijekom NM i FM. Parametri okoliša koji su praćeni pokazuju značajne razlike u odnosu na mjesečevu fazu. Mrijest školjkaša $C$. senatoria slijedi mjesečev ciklus, na koji pokreče i utječe na varijacije različitih čimbenika poput temperature, amplitude vode i svjetlosti kao učinak mjesečevih / plimnih ciklusa. Ova otkrića ukazuju da su razmnožavanje i nužno mrijest u $C$. senatoria povezani s čimbenicima povezanim $s$ mjesečevim fazama. Strategije upravljanja resursima mogu se formulirati korištenjem vremenske dimenzije lunarnih faza.

Ključne riječi: razmnožavanje, mjesečeva periodičnost, egzogeni čimbenici

\section{REFERENCES}

Acabado, C. S., Guarte, D. M., Paraboles, L. C., Campos, W. L. (2018): The fisheries profile of Gigantes Islands, Carles, Philippines and Notes on its Scallop Fishery History. Philippine Journal of Natural Science, 22, 3747.

Amirthalingam, C. (1928): On Lunar Periodicity in reproduction Pecten opercularis near Plymouth in $1927-28$.

Barber, B. J., Blake, N. J. (1983): Growth and reproduction of the bay scallop, Argopecten irradians (Lamarck) at its southern distributional limit. Journal of Experimental Marine Biologyg and Ecology 66, 247-256.

Barber, B. J., Blake, N. J. (1991): Reproductive Physiology. In: S.E. Shumway (Ed.). Scallops: Biology, Ecology and Aquaculture. Elsevier, New York. pp. 377-428.

Berry, A. J., Smith, S. M. (1987): Aspects of the molluscan fauna of the rocky shores of the Firth of Forth and Forth estuary, Scotland. Proceedings of the Royal Society of Edinburgh. Section B. Biological Sciences, 93, 3-4, 431447.

Berry, A. J. (1986): Semi-lunar and lunar spawning periodicity in some tropical littorinid gastropods. Journal of Molluscan Studies, 52, 144-149.

Bobiles, R. U., Soliman, V. S. (2018): Fishery of commercial scallops in Asid Gulf, Philippines. Aquaculture Aquarium Conservation and Legislation Bioflux, 11, 4, 1265-1273.

Brand, A.R. (2006): Scallop ecology: distributions and behavior. In: Shumway, S.E. \& G. J. Parsons, editors. Scallops: biology, ecology and aquaculture. Amsterdam, The Netherlands: Elsevier, 651-744.

Buban, I. C. R., Cabiles, C. D., Bobiles, R. U., Camaya, A. P., Soliman, V. S. (2020): Sinusoidal growth, recruitment, mortality, yield-per-recruit analysis of Buried fan scallop Mimachlamys funebris (Reeve, 1853) and their implications for mariculture. Journal of Fisheries, 8(2),
828-836.

Cabiles, C. D., Soliman, V. S. (2019): Reproduction temperature-nexus influencing spawning of pectinids in tropical and temperate waters. Aquaculture Aquarium Conservation and Legislation Bioflux, 12, 1, 63-72.

Cabiles, C. D., Buban I. C. R., Soliman, V. S., Bobiles, R. U., Camaya, A. P. (2019): Population parameters and exploitation of commercial scallop fishery for Chlamys nobilis in Asid Gulf, Philippines. International Journal of Biosciences, 15, 2, 118-131.

Colin, P. L., Shapiro D. Y., Weiler D. (1978): Aspects of the reproduction of two species of groupers, Ephenephelus gutatus and $E$. striatus in the West Indies. Bulletin of Marine Science, 40, 2, 220-230.

Creese, R. G. (1980): Reproductive cycles and fecundity of two species Siphonaria (Mollusca: Pulmonata) in south-eastern Australia. Marine and Freshwater Research, 31, 1, 37-47.

Del Norte, A. G. C. (1991): Aspects of the growth, recruitment, mortality and reproduction of the scallop Amusium pleuronectes (Linne) in the Lingayen Gulf, Philippines. Ophelia, 29, 153-168.

Dickie, L. M. (1953): Fluctuations in abundance of the giant scallop Placopecten magellanicus (Gmelin), in the Digby area of the Bay of Fundy. Journal of the Fisheries Research Board of Canada, 12, 6, 797-857.

Dukeman, A. K., Blake, N. J., Arnold, W. S. (2005): The reproductive cycle of the flame scallop, Ctenoids scaber (Born 1778), from the lower florida keys and its relationship with environmental conditions. Journal of Shellfish Research, 24, 2, 341-351.

Fuerte, M. V., Baez R. I. O. (1993): The reproductive cycle of the Scallop Argopecten circularis (Sowerby, 1835) in relation to temperature and photoperiod in Bahia Concepcion, B.C.S., Mexico, Ciencias Marinas, 19, 2,181-202.

Gosling, E. (2003). Bivalve growth. Bivalve molluscs: biology ecology and culture. In Fishing News Books Blackwell Oxford, 169-200 pp.

Hamli, H., Idris, M. H., Rajaee, A. H., Kamal, A. H. M. (2015): Reproductive cycle of hard clam, Meretrix lyrata Sowerby 1851 (Bivalvia: Veneridae) from Sarawak, Malaysia. Tropical Life Sciences Research, 26, 2, 59.

Hardy, D. (2006): Scallop farming $2^{\text {nd }}$ Edition. Oxford: Blackwell Publishing, 59-65 pp.

Heald, D. I., Caputi, N. (1981): Some aspects of growth, recruitment and reproduction in the southern saucer scallop, Amusium balloti (Bernardi, 1861) in Shark Bay, Western Australia. Fisheries Research Bulletin (Western Australia), 25, 1-33.

Johannes, R. E. (1978): Reproductive strategies of coastal marine fishes in the tropics. Environmental biology of Fishes, 3, 65-84

Kawamata, K. (1983): Reproductive cycle of the scallop, Patinopecten yessoensis (Jay), planted in Funka Bay, Hokkaido. Scientific Report of Hokkaido Fisheries Experimental Station (Japan), 25,15-20. 
Korringa, P. (1947): Relations between the moon and the periodicity in the breeding of marine animals. Ecological Monographs, 17, 349-381.

Langton, R. W., Robinson, W. E., Schick, D. (1987): Fecundity and reproductive effort of sea scallops Placopecten magellanicus from the Gulf of Maine. Marine Ecology-Progress Series, 37, 19-25.

Lefort, Y., Clavier, J. (1993): Reproduction of Annachlamys flabellata, Comptopallium radula and Mimachlamys gloriosa (Mollusca: Pectinidae) in the south-west lagoon of New Caledonia. Aquatic Living Resources, 7, 39.46.

Lucas, J., Southgate, P. (2012): Aquaculture: Farming aquatic animals and plants. John Wiley \& Sons, 129130.

Mason, J. (1958): The breeding of the scallop, Pecten maximus (L.) in Manx waters. Journal of Marine Biological Association of the United Kingdom, 37, 653671.

McDowall, R. M. (1970): Lunar rhythms in aquatic animals: a general review. Tuatara, 17, 133-144.

Mendoza, A. B., Soliman, V. S. (2017): Coastal habitats of Asid Gulf, Masbate, Philippines: Assessment and role of marine protected areas for management development. Aquaculture Aquarium Conservation and Legislation Bioflux, 10, 5, 1351-1359.

Miller, G. C., Allen, D. M., Costello, T. J. (1981) Spawning of the calico scallop Argopecten gibbus in relation to season and temperature. Journal of Shellfish Research, 1, 17-21.

Minchin, D. (2003): Introductions: Some biological and ecological characteristics of scallops. Aquatic Living Resources, 16, 521-532.

Morillo, L. M., Quinitio, G. F., Laureta, L. V., Añasco, N. C., Monteclaro, H. M. (2016): Ecology and Reproductive biology of Senatorial Scallop Chlamys senatoria (Gmelin 1791) In Gigantes Island, Carles, Central Philippines. Journal of Shellfish Research, 35, 1, 17-25.

Naidu, K. S. (1970): Reproduction and breeding cycle of the giant scallop Placopecten magellanicus (Gmelin) in Port au Port Bay, Newfounland. Canadian Journal of Zoology, 48, 5, 1003-1012.

Olive, P. J., Lewis, C., Beardall, V. (2000): Fitness components of seasonal reproduction: an analysis using Nereis virens as a life history model. Oceanologica Acta, 23, 377-389.

Orton, J. (1926): On lunar periodicity in spawning of normally grown Falmouth oyster (O. edulis) in 1925, with a comparison of the spawning capacity of normally grown and dumpy oyster. Journal of the Marine Biological Association of the United Kingdom, 14, 1, 199-225.

Parsons, G. J., Robinson, S. M. C., Chandler, R. A., Davidson, L. A., Lanteigne, M., Dadswell, M. J. (1992): Intra-annual and long-term patterns in the reproductive cycle of giant scallops Placopecten magellanicus (Bivalvia: Pectinidae) from Passamaquoddy Bay, New Brunswick,
Canada. Marine Ecological Progress Series, 80, 203214.

Sarkis, S., Couturier, C., Cogswell, A. (2006). Reproduction and spawning in calico scallops Argopecten gibbus from Bermuda. Journal of Shellfish Research, 25, 2, 503-508.

Sastry, A. N. (1963): Reproduction of the bay scallop Aequipecten irradians Lamarck. Influence of temperature on maturation and spawning. Biological Bulletin, 125, 1, 146-153.

Sastry, A. N. (1970): Reproductive physiological variation in latitudinally separated populations of the bay scallops, Argopecten irradians Lamark. The Biological Bulletin 138, 1, 56-65.

Sastry, A. N. (1979): Pelecypoda (excluding Ostreidae). In: A.C. Giese and J.S. Pearse (Eds). Reproduction of Marine Invertebrates. Academic Press, New York. pp. 113-292.

Shumway, S. E., Parsons, G. J. (2016): Scallop: biology, ecology, aquaculture, and fisheries. Elsevier, London, UK.

Sienes, R. K. A., Juranes Jr, R. S., Metillo, E. B. (2018): Lunar periodicity in reproduction of two venerid clams Meretrix meretrix and Katelysia hiantina in Panguil Bay, Northern Mindanao, Philippines. International Journal of Biosciences, 13, 6, 70-81.

Skov, M. W., Hartnoll, R. G., Ruwa, R. K., Shunula, J. P., Vannini, M., Cannici, S. (2005): Marching to a different drummer: crabs synchronize reproduction to a 14-month lunar-tidal cycle. Ecology, 86, 5, 1164-1171.

Soliman V. S., Dioneda R. (2004) Quick Stock Assessment of Commercial Scallops (Bivalvia: Pectinidae) in Asid Gulf, Masbate. University of the Philippines in the Visayas Journal of Natural Science, 9, 1, 165-176.

Stevenson, J. A. (1936): The Canadian scallop - Its fishery, life history and some environmental relationship. M. A. thesis. University of Western Ontario, London, Ontario. Fish Res. Bd. Can. MS Rep. Biol. Sta. No. 373.

Tang, S. F. (1941): The breeding of scallop (Pecten maximus L.) with a note on the growth rate. Proc. Liverpool Biol. Soc., 54, 9-28.

Tan, A., Yasin, Z. (2001): Factors affecting the dispersal of Tridacna squamosa larvae and gamete material in Tioman Archipelago, the South China Sea. Phuket Marine Biological Center Special Publication, 25, 349356.

Tettelbach, S. T., Smith, C. F., Smolowitz, R., Tetrault, K., Dumais, S. (1999): Evidence for fall spawning of northern bay scallops Argopecten irradians irradians (Lamarck, 1819) in New York. Journal of Shellfish Research, 18, 1, 47-58.

Telahigue, K., Hajji, T., Cafsi, M., Saavedra, C. (2018): Genetic structure and demographic history of the endemic Mediterranean scallop Pecten jacobaeus inferred from mitochondrial 16s DNA sequence analysis. Animal and Biodiversity Conservation, 41, 1, 61-73.

Thorarinsdottir, G. G. (1993): The Iceland scallop, Chlamys 
islandica (O.F. Muller), in Breidafjordur, West Iceland II. Gamete development and spawning. Aquaculture, 110, 87-96.

Tran, D., Nadau, A., Durrieu, G., Ciret, P., Parisot, J. P., Massabuau, J. C. (2011): Field Chronobiology of a Molluscan Bivalve: How the Moon and Sun Cycles Interact to Drive Oyster Activity Rhythms. Chronobiology International, 28, 4, 307-317.

Ursin, E. (1956): Distribution and growth of the queen Chlamys opercularis (Lamellibranchiata), in Danish and Faroese waters. Medd. Dan. Fisk. Havunders, 13, 32.
Wilson, D. P. (1951): Life of the shore and shallow sea. $2^{\text {nd }}$ Edition. Nicholson and Watson, London, p213.

Wong, K. L. C. (2016): Nutrition and reproductive condition of wild and cultured New Zealand scallops (Pecten novaezelandiae). Unpublished PhD Thesis, University of Auckland.

Yamahira, K. (2004): How do multiple environmental cycles in combination determine reproductive timing in marine organisms? A model test. Functional Ecology, 18, 4-15. 